\title{
School meals, school milk and height of primary school children in England and Scotland in the eighties
}

\author{
ROBERTO J RONA AND SUSAN CHINN \\ From the Division of Community Health, United Medical and Dental Schools of Guy's and St. Thomas's Hospitals, \\ London
}

ABSTRACT In a nutritional surveillance system of primary school children in England and Scotland we assessed the possible effects on height gain of changes in school meals and school milk policies following the 1980 Education Act (No. 2). Mean height and height gain were estimated separately for English and Scottish samples from 1982 to 1984, and for a selective sample of inner city areas with a high proportion of ethnic minorities from 1983 to 1985 in children from 5.00 to 9.99 years. Children receiving free school meals were smaller than children paying for school meals or receiving a meal prepared elsewhere, while children receiving free school milk were of similar stature to other children in the study. The rate of growth was assessed in children receiving school meals or lunches prepared at home, and in those for whom arrangements changed during the study period; it was also assessed in those children for whom school milk was available, not available, or for whom the provision changedo No consistent association was found between provision of school meals or school milk and the rate of growth in the three samples studied when stratified according to poverty status and ethni\& background. We conclude that this observational study does not provide any evidence that the current availability of school meals or school milk increases the rate of growth of primary schood children in any social stratum.

From 1944 to 1980 Local Education Authorities in the United Kingdom were obliged to provide a midday meal that was to meet all the requirements appropriate to the main meal of the day. ${ }^{12}$ The Education Act (1980) gave them freedom to decide the form and content of and the charges to be made for school meals, but they were required to provide free school meals to children from families receiving Family Income Supplement or Supplementary Benefit. As a result of these changes there was a large fall in the percentage of English children receiving school meals, from $66 \%$ in 1978 to $51 \%$ in 1984 and a moderate decrease from $47 \%$ in 1978 to $42 \%$ in 1985 in Scotland. ${ }^{3}$ During this period the provision of free school meals increased in England and Wales but it remained around the same level in Scotland. In parallel there has been a change in the format of the midday lunch. In schools in the National Study of Health and Growth, ${ }^{4}$ although a traditional lunch of meat, two vegetables and sweet continues to be the most popular type of midday refreshment, approximately a quarter operate an individually priced item system or a mixed system.

Free school milk provision has also been through several changes. Free distribution was withdrawn first to secondary school children in 1968 , then after the seventh birthday in 1971, and finally, since 1980, Local Authorities have no statutory obligation to provide it to any school child. However, under a European Community scheme, a subsidy has been payable since 1983 on milk and milk products and, although the scheme is optional, children in about 37000 schools in the UK receive subsidised milk. ${ }^{3}$

Since 1972 information on growth, family social background and receipt of school meals and milk has been collected in a nutritional surveillance system of primary school children. From this and a contemporary study it was possible to assess the value of food provided in the school in terms of milk ${ }^{5}$ and meals. ${ }^{7}$ With respect to school milk it was shown that in contrast to pre-war studies which showed a significant effect of milk on growth ${ }^{89}$ there was no association between school milk and the rate of growth in the observational study. ${ }^{5} \mathrm{~A}$ borderline significant positive association in the girls but not the boys of the lowest socio-economic group was found in a randomised controlled trial in Wales. ${ }^{6}$ No association between uptake of school meals and rate of growth was found in England and Scotland regardless of the social background of the group. ${ }^{7}$ 
All these studies were based on children measured during the seventies. Since 1979 the unemployment rate has greatly increased, with a small recent fall in numbers ${ }^{10}$ and, as explained above, the entitlement to food at school has greatly changed. Under these new social conditions it is of great importance to examine to what extent the reported findings for the seventies are still applicable in Britain today. In this report the value of school meals and milk is assessed in terms of growth rate of children attending (with a few exceptions) the same schools as those for whom data were used in our previous analyses. ${ }^{57} \mathrm{~A}$ similar assessment is made of children from inner city areas who have been followed up every 2 years since 1983 and include a large number of children from ethnic minorities. ${ }^{11}$

\section{Methods}

This report is based on information from three samples: an English sample obtained from a stratified random sampling of employment exchange areas with proportionally more from poorer social groups; ${ }^{12}$ a similarly selected Scottish sample; and a third from wards of English County and London Boroughs selected to give 10 areas with characteristics of inner city areas (high unemployment, high household overcrowding and low percentage of exclusive use of all basic amenities), five areas with a high percentage of Afro-Caribbeans and another five with a high percentage of people originally from the Indian subcontinent. ${ }^{11}$ The English and Scottish samples obtained from the original 1972 sampling frames have been found to be very similar, from a sociodemographic view, to a representative sample ${ }^{11}$ and will be described as the English and Scottish representative samples, while the sample obtained from the English County and London Boroughs will be designated the selective sample. Each study area is visited every 2 years, the Scottish representative sample being divided between even and odd years. The information in this report for the English representative sample was obtained in 1982 and 1984, for the Scottish representative sample in 1982 or 1983 and 1984 or 1985, and for the selective sample in 1983 and 1985.

All children in the age range 5 to 11 years in the selected schools were the target population. However for these analyses only children in the age range 5 to 9 years old in the 1982 or 1983 surveys were included, since longitudinal data were required and 10 or 11 year old children in the initial survey (1982 or 1983) were not attending school in the subsequent survey (1984 or 1985). Height was measured by local nurses supervised by fieldworkers using a specially designed stadiometer (Holtain) following a technique described elsewhere ${ }^{13}$ and based on recommendations of Tanner, Whitehouse and Takaishi. ${ }^{14}$

It is generally accepted that height is the measure of choice to assess nutritional status or changes in nutritional status in countries in which severe malnutrition is rare or non-existent. ${ }^{115}$ Results for height are presented in terms of a standard deviation score (SDS). This was calculated for each child as the difference between the child's height and the mean height of children of the same age, sex and country (England and Scotland) divided by the standard deviation for that group. This method of expressing height standardises for age and sex and the increasing variance of height with increasing age. One SDS is equivalent to about 5 centimetres at age 5 and about 7 centimetres at age 11. Means and standard deviations from 1982 data were used. The following information relevant to this paper was obtained from the self administered questionnaire: father's social class and employment status, receipt of family income supplement and supplementary benefit, number of children in the family, receipt of school meals, and availability of school milk and whether either was provided free of charge.

Two main analyses were performed, the first to assess the difference in attained height between children who received free school meals, those who paid for school meals and those who had a lunch prepared outside the school scheme. In the second analysis the difference in height SDS in the two surveys was compared in a multiple regression analysis between groups according to whether the child received school meals in both surveys, only had school meals in one survey, or did not have school meals in either survey. The same analyses were also carried out according to availability of school milk. As school milk in the English representative sample was mainly available to younger children in the school, age was added as independent factor in the analysis.

In the analysis of rate of growth the children of the English and Scottish representative samples were divided into three groups: poor, uncertain and not poor. Poverty was operationally defined as a child who fulfilled at least one of the following characteristics: father in social class V; father in social class IV and four or more siblings; receipt of family income supplement or supplementary benefit. Any child who had none of these characteristics was designated to be in the "not poor" group. Those whose parents gave incomplete information which did not classify them in the poor group were classified in the uncertain group.

In the selective sample the groups were divided according to ethnic origin instead of by poverty index. The groups were Caucasians, Afro-Caribbeans, Urdu, Gujarati, Punjabi, "Other Asians" and "Others". The classification was based on fieldworker's subjective 
Table 1 Percentage uptake of school meals* and free school meals by father's social class in the English and Scottish representative samples and the English selective sample

\begin{tabular}{|c|c|c|c|c|c|c|c|c|c|}
\hline \multirow[b]{4}{*}{$\begin{array}{l}\text { Father's social class } \\
\text { Professionals (I) } \\
\text { Managers (II) } \\
\text { Clerks (IIINM) } \\
\text { Skilled manual (IIIM) } \\
\text { Semi-skilled manual (IV) } \\
\text { Unskilled manual (V) } \\
\text { Mother headed one parent families } \\
\text { Others }\end{array}$} & \multicolumn{6}{|c|}{ England } & \multirow{2}{*}{\multicolumn{3}{|c|}{$\frac{\text { Scotland }}{\text { Representative sample }}$}} \\
\hline & \multicolumn{3}{|c|}{ Representative sample } & \multicolumn{3}{|c|}{ Selective sample } & & & \\
\hline & $\bar{n}$ & $\%+C$ & $\%$ tFree & $n$ & $\% U_{l}$ & $\%$ Free & $n$ & $\% U$ & $\%$ Free \\
\hline & $\begin{array}{r}248 \\
922 \\
319 \\
1462 \\
458 \\
110 \\
412 \\
406\end{array}$ & $\begin{array}{l}35 \cdot 9 \\
47 \cdot 3 \\
46 \cdot 5 \\
52 \cdot 7 \\
59 \cdot 4 \\
65 \cdot 5 \\
75 \cdot 5 \\
60 \cdot 1\end{array}$ & $\begin{array}{r}0.0 \\
2.3 \\
4.7 \\
8.5 \\
11.6 \\
31.8 \\
52.9 \\
28.3\end{array}$ & $\begin{array}{r}44 \\
211 \\
142 \\
1024 \\
558 \\
231 \\
1047 \\
610\end{array}$ & $\begin{array}{l}59 \cdot 1 \\
68 \cdot 2 \\
58 \cdot 5 \\
71 \cdot 6 \\
73 \cdot 7 \\
80 \cdot 5 \\
84 \cdot 3 \\
76 \cdot 6 \\
\end{array}$ & $\begin{array}{r}2.3 \\
17.5 \\
19.0 \\
34.9 \\
41.9 \\
63.6 \\
66.6 \\
49.4\end{array}$ & $\begin{array}{l}105 \\
479 \\
176 \\
951 \\
333 \\
115 \\
325 \\
161\end{array}$ & $\begin{array}{l}23.8 \\
23.0 \\
17.6 \\
26.8 \\
38.7 \\
53.0 \\
73.2 \\
52.8 \\
\end{array}$ & $\begin{array}{r}1.9 \\
0.8 \\
1.7 \\
10.2 \\
17.7 \\
42.6 \\
59.1 \\
39.1 \\
\end{array}$ \\
\hline
\end{tabular}

* Children for whom no information on school meals was obtained are not included

$\dagger$ Both percentages are of the total number of children in the group.

assessment and the language spoken at home. The group "Other Asians" is an heterogeneous group of children who were originally from the Indian subcontinent but not from the three groups identified above, and the group "Others" included all children who were not classified in any of the other categories. ${ }^{11}$

\section{Results}

Table 1 shows the percentage uptake of school meals and the percentage of free school meals by social class and for one parent families in the first survey. In England there was a clear tendency to greater uptake of school meals and of free school meals to children in lower social classes. Greater uptake was mainly observed in social classes IV and V in Scotland. A very high availability of school meals was observed for children of one parent families. In the selective English sample the percentage uptake of school meals was higher than in the corresponding group in the representative sample, as was the percentage of children receiving free school meals.

In table 2 the percentages of school meals and free school meals by ethnic group are given. The percentages of uptake of school meals was consistently lower in Asian groups than any other ethnic group. The uptake was very high in the Caucasians, AfroCaribbean and "Other" groups. Only a minority of the children in these groups were not receiving school meals in 1983 and a large percentage of the children were entitled to free school meals.

Table 2 Percentage uptake of school meals and free school meals* by ethnic group in the selective sample

\begin{tabular}{llll}
\hline & $n$ & $\%$ t Uptake & $\%+$ Free \\
\hline Caucasian & 1514 & 82.8 & 54.2 \\
Afro-Caribbean & 465 & 93.1 & 52.0 \\
Urdu & 288 & 63.9 & 42.7 \\
Gujarati & 348 & 66.1 & 40.8 \\
Punjabi & 812 & 60.6 & 36.7 \\
Other Asians & 152 & 59.9 & 34.9 \\
Others & 261 & 86.6 & 43.7 \\
Not known & 27 & 85.2 & 40.7 \\
\hline
\end{tabular}

- Children for whom no information on school meals was obtained are not - Children for whom no information on school meals was obtained are
included.
+ Both percentages are of the total number of observations in the group.

Table 3 gives the percentage of children for whom school milk was available in each social class in the three samples. The provision of school milk in 1982 and 1983 was unrelated to social class in all three samples. However the school milk scheme reached a very high percentage of provision in the selective sample, approximately half of the Scottish children and a quarter of the English children in the representative samples. For most children the school milk was available free of charge particularly in the Scottish selective samples.

The school meals scheme was unrelated to child's age in any of the samples, while school milk was predominantly provided to the children below 8 years in the English representative sample. In older children school milk was available to a sizeable number in the

Table 3 Provision of school milk and free school milk by father's social class in the English representative and selective samples, and in the Scottish representative sample

\begin{tabular}{|c|c|c|c|c|c|c|c|c|c|}
\hline \multirow[b]{3}{*}{ Social class } & \multicolumn{6}{|c|}{ England } & \multirow{2}{*}{\multicolumn{3}{|c|}{$\frac{\text { Scotland }}{\text { Representative sample }}$}} \\
\hline & \multicolumn{3}{|c|}{ Representative sample } & \multicolumn{3}{|c|}{ Selective sample } & & & \\
\hline & $n$ & $\%$ Availability & $\%$ Free & $n$ & $\%$ Availability & $\%$ Free & $\bar{n}$ & $\%$ Availability & $\%$ Free \\
\hline $\begin{array}{l}\text { Professionals (I) } \\
\text { Managers (II) } \\
\text { Clerks (IIINM) } \\
\text { Skilled manual (IIIM) } \\
\text { Semi-skilled manual (IV) } \\
\text { Unskilled manual (V) }\end{array}$ & $\begin{array}{r}248 \\
919 \\
317 \\
1451 \\
458 \\
109\end{array}$ & $\begin{array}{l}29 \cdot 8 \\
30 \cdot 4 \\
25 \cdot 6 \\
26 \cdot 2 \\
22 \cdot 1 \\
29 \cdot 4\end{array}$ & $\begin{array}{l}9 \cdot 7 \\
12 \cdot 6 \\
13 \cdot 2 \\
19 \cdot 8 \\
16 \cdot 2 \\
21 \cdot 1\end{array}$ & $\begin{array}{r}44 \\
204 \\
140 \\
1006 \\
550 \\
227\end{array}$ & $\begin{array}{l}75 \cdot 0 \\
70 \cdot 6 \\
75 \cdot 0 \\
63 \cdot 3 \\
62 \cdot 7 \\
63 \cdot 4\end{array}$ & $\begin{array}{l}65 \cdot 9 \\
67 \cdot 2 \\
69 \cdot 3 \\
58 \cdot 7 \\
59 \cdot 8 \\
60 \cdot 8\end{array}$ & $\begin{array}{l}109 \\
478 \\
178 \\
958 \\
341 \\
115\end{array}$ & $\begin{array}{l}48 \cdot 6 \\
47 \cdot 1 \\
51 \cdot 1 \\
61 \cdot 7 \\
49 \cdot 8 \\
61 \cdot 7\end{array}$ & $\begin{array}{l}47 \cdot 7 \\
46 \cdot 0 \\
49 \cdot 4 \\
59 \cdot 5 \\
47 \cdot 8 \\
59 \cdot 1\end{array}$ \\
\hline $\begin{array}{l}\text { Mother headed one parent } \\
\text { families } \\
\text { Others }\end{array}$ & $\begin{array}{l}401 \\
434\end{array}$ & $\begin{array}{l}24.9 \\
30.0\end{array}$ & $\begin{array}{l}21.4 \\
24.9\end{array}$ & $\begin{array}{r}1016 \\
598\end{array}$ & $\begin{array}{l}62 \cdot 1 \\
64 \cdot 4\end{array}$ & $\begin{array}{l}58.5 \\
59.2\end{array}$ & $\begin{array}{l}320 \\
164\end{array}$ & $\begin{array}{l}66 \cdot 3 \\
60 \cdot 4\end{array}$ & $\begin{array}{l}64.7 \\
58.5\end{array}$ \\
\hline
\end{tabular}

Children with no data on school milk were excluded. 
Table 4 Height in SDS of children by type of lunch or availability of school milk in the English and Scottish representative samples and the English selective sample

\begin{tabular}{|c|c|c|c|c|c|c|c|c|c|}
\hline & $\begin{array}{l}\text { English } \\
n\end{array}$ & $\begin{array}{l}\text { presentative } \\
\text { mean }\end{array}$ & $(S E)$ & $\begin{array}{l}\text { Englis } \\
n\end{array}$ & $\begin{array}{l}\text { lective } \\
\text { mean }\end{array}$ & $(S E)$ & $\begin{array}{l}\text { Scottish } \\
n\end{array}$ & $\begin{array}{l}\text { epresentative } \\
\text { mean }\end{array}$ & $(S E)$ \\
\hline $\begin{array}{l}\text { School meals } \\
\text { Free school lunch } \\
\text { Paid for school lunch } \\
\text { Uncertain if free school lunch } \\
\text { Lunch prepared at home } \\
\text { Others }\end{array}$ & $\begin{array}{r}568 \\
1503 \\
269 \\
1931 \\
528\end{array}$ & $\begin{array}{r}-0.29 \\
0.07 \\
-0.13 \\
0.08 \\
-0.15\end{array}$ & $\begin{array}{l}(0.04) \\
(0.03) \\
(0.06) \\
(0.02) \\
(0.04)\end{array}$ & $\begin{array}{r}1777 \\
875 \\
237 \\
926 \\
716\end{array}$ & $\begin{array}{r}-0.15 \\
0.15 \\
-0.11 \\
-0.05 \\
-0.03\end{array}$ & $\begin{array}{l}(0.03) \\
(0.04) \\
(0.07) \\
(0.04) \\
(0.04)\end{array}$ & $\begin{array}{r}466 \\
390 \\
68 \\
1691 \\
715\end{array}$ & $\begin{array}{r}-0.32 \\
0.13 \\
-0.13 \\
0.13 \\
0.08\end{array}$ & $\begin{array}{l}(0.05) \\
(0.05) \\
(0.13) \\
(0.02) \\
(0.07)\end{array}$ \\
\hline $\begin{array}{l}\begin{array}{l}\text { School milk } \\
\text { School milk available-free } \\
\text { not free } \\
\text { uncertain if free }\end{array} \\
\text { School milk not available } \\
\text { Others }\end{array}$ & $\begin{array}{r}730 \\
356 \\
52 \\
3104 \\
557 \\
\end{array}$ & $\begin{array}{r}-0.08 \\
0.19 \\
0.15 \\
-0.01 \\
0.14 \\
\end{array}$ & $\begin{array}{l}(0.04) \\
(0.06) \\
(0.13) \\
(0.02) \\
(0.04)\end{array}$ & $\begin{array}{r}2238 \\
61 \\
92 \\
1342 \\
798 \\
\end{array}$ & $\begin{array}{r}-0.00 \\
0.28 \\
-0.34 \\
0.17 \\
0.01\end{array}$ & $\begin{array}{l}(0.02) \\
(0.16) \\
(0.11) \\
(0.03) \\
(0.04)\end{array}$ & $\begin{array}{r}1448 \\
13 \\
33 \\
1140 \\
156\end{array}$ & $\begin{array}{r}-0.03 \\
0.03 \\
-0.11 \\
0.13 \\
0.08\end{array}$ & $\begin{array}{l}(0.03) \\
(0.19) \\
(0.15) \\
(0.03) \\
(0.08)\end{array}$ \\
\hline
\end{tabular}

Scottish and selective samples. Children receiving free school meals were shorter than children in other groups within each sample (table 4). Children in the representative samples who paid for school meals or received a lunch prepared at home were of similar height. In the selective sample, with the exception of the Gujarati and Punjabi groups, children who paid for the school meals were taller than children not subscribing to the school meals scheme. Children receiving free school milk were slightly shorter than other children in the representative samples but not in the selective sample (table 4).

Table 5 gives the rate of growth in terms of change in SDS by uptake of school meals and availability of milk in two successive surveys, and social background for the English and Scottish representative samples. The samples were analysed into three groups according to social status in the first survey (poor, undefined, not poor).

There were some significant associations between change in SDS and school meals in England and Scotland. However these significant associations were not consistent by country and social status. In the total English sample the rate of growth was difficult to interpret due to the lack of consistency between the association of school meals and rate of growth by social status (interaction $\mathrm{p}<0 \cdot 1$ ). In the poor group the rate of growth was the greatest in the children not receiving school meals (overall difference between three groups $p<0 \cdot 1)$ whereas the rate of growth was the greatest in children receiving school meals in the not poor group $(p<0.05)$. In the total Scottish sample the lowest rate of growth was in the group of children receiving school meals $(\mathrm{p}<0 \cdot 1)$, although not significant in any of the three status groups alone.

In Scotland children provided with school milk at the time of one of the surveys had the greatest rate of growth while the children not provided with milk had the lowest rate of growth $(p<0.05)$. In England there was no association between school milk and the rate of growth.

A similar analysis was carried out for each ethnic group in the selective sample. Only one significant association was detected in the association between type of school meals and rate of growth. In the Caucasian children those receiving lunch prepared at home had the greatest rate of growth (table 6).

In the corresponding analysis of the association between school milk and rate of growth most of the results showed no association between these variables. In the Afro-Caribbean, "Other Asians" and "Other" groups some of the subsets were too small for useful analysis.

Table 5 Mean change in height SDS by type of lunch or availability of school milk and level of poverty in the English and Scottish representative samples

\begin{tabular}{|c|c|c|c|c|c|c|c|c|c|c|c|c|}
\hline & \multicolumn{3}{|l|}{ Poor } & \multicolumn{3}{|c|}{ Uncertain } & \multicolumn{3}{|c|}{ Not poor } & \multicolumn{3}{|l|}{ Total } \\
\hline & $n$ & mean & $(S E)$ & $n$ & mean & $(S E)$ & $n$ & mean & $(S E)$ & $n$ & mean & $(S E)$ \\
\hline $\begin{array}{l}\text { England } \\
\text { School lunch } \\
\text { Changed scheme } \\
\text { Lunch prepared elsewhere } \\
\text { Differences in means }\end{array}$ & $\begin{array}{r}306 \\
73 \\
68\end{array}$ & $\begin{array}{c}-0.039 \\
-0.099 \\
0.024 \\
\dagger\end{array}$ & $\begin{array}{l}(0.017) \\
(0.035) \\
(0.036)\end{array}$ & $\begin{array}{r}144 \\
86 \\
90\end{array}$ & $\begin{array}{c}-0.011 \\
0.019 \\
0.000 \\
-\end{array}$ & $\begin{array}{l}(0.029) \\
(0.037) \\
(0.036)\end{array}$ & $\begin{array}{l}851 \\
432 \\
981\end{array}$ & $\begin{array}{l}-0.015 \\
-0.057 \\
-0.045\end{array}$ & $\begin{array}{l}(0.010) \\
(0.014) \\
(0.009)\end{array}$ & $\begin{array}{r}1301 \\
591 \\
1139\end{array}$ & $\begin{array}{c}-0.013 \\
-0.046 \\
-0.031 \\
\text { Int }\end{array}$ & $\begin{array}{l}(0.009) \\
(0.013) \\
(0.011)\end{array}$ \\
\hline $\begin{array}{l}\text { Milk available } \\
\text { Milk available in one survey } \\
\text { Milk not available } \\
\text { Differences in means }\end{array}$ & $\begin{array}{r}19 \\
19 \\
306\end{array}$ & $\begin{array}{r}0.038 \\
-0.020 \\
-0.039 \\
-\end{array}$ & $\begin{array}{l}(0.064) \\
(0.064) \\
(0.016)\end{array}$ & $\begin{array}{r}22 \\
30 \\
144\end{array}$ & $\begin{array}{c}-0.076 \\
-0.020 \\
-0.007 \\
-\end{array}$ & $\begin{array}{l}(0.085) \\
(0.073) \\
(0.033)\end{array}$ & $\begin{array}{r}104 \\
73 \\
849\end{array}$ & $\begin{array}{r}0.003 \\
-0.050 \\
-0.015 \\
-\end{array}$ & $\begin{array}{l}(0.027) \\
(0.032) \\
(0.009)\end{array}$ & $\begin{array}{r}145 \\
122 \\
1299\end{array}$ & $\begin{array}{l}-0.007 \\
-0.038 \\
-0.010 \\
-\end{array}$ & $\begin{array}{l}(0.025) \\
(0.027) \\
(0.010)\end{array}$ \\
\hline $\begin{array}{l}\text { Scotland } \\
\text { School lunch } \\
\text { Changed scheme } \\
\text { Lunch prepared elsewhere } \\
\text { Differences in means }\end{array}$ & $\begin{array}{r}223 \\
88 \\
83\end{array}$ & $\begin{array}{c}-0.094 \\
-0.038 \\
-0.063 \\
-\end{array}$ & $\begin{array}{l}(0.027) \\
(0.043) \\
(0.044)\end{array}$ & $\begin{array}{l}50 \\
42 \\
81\end{array}$ & $\begin{array}{l}-0.050 \\
-0.017 \\
-0.017 \\
-\end{array}$ & $\begin{array}{l}(0.044) \\
(0.048) \\
(0.035)\end{array}$ & $\begin{array}{l}221 \\
281 \\
990\end{array}$ & $\begin{array}{c}-0.088 \\
-0.047 \\
-0.037 \\
-\end{array}$ & $\begin{array}{l}(0.024) \\
(0.021) \\
(0.011)\end{array}$ & $\begin{array}{r}494 \\
411 \\
1154\end{array}$ & $\begin{array}{l}-0.080 \\
-0.033 \\
-0.034 \\
t\end{array}$ & $\begin{array}{l}(0.018) \\
(0.020) \\
(0.015)\end{array}$ \\
\hline $\begin{array}{l}\text { Milk avarlable } \\
\text { Milk available in one survey } \\
\text { Milk not available } \\
\text { Differences in means }\end{array}$ & $\begin{array}{r}53 \\
53 \\
220\end{array}$ & $\begin{array}{c}-0.064 \\
-0.047 \\
-0.094 \\
- \\
\end{array}$ & $\begin{array}{l}(0.054) \\
(0.054) \\
(0.027)\end{array}$ & $\begin{array}{l}55 \\
24 \\
50\end{array}$ & $\begin{array}{c}-0.050 \\
-0.043 \\
-0.061 \\
- \\
\end{array}$ & $\begin{array}{l}(0.038) \\
(0.057) \\
(0.040)\end{array}$ & $\begin{array}{l}692 \\
124 \\
212\end{array}$ & $\begin{array}{c}-0.026 \\
-0.020 \\
-0.095 \\
t\end{array}$ & $\begin{array}{l}(0.014) \\
(0.034) \\
(0.026)\end{array}$ & $\begin{array}{l}800 \\
201 \\
482\end{array}$ & $\begin{array}{l}-0.031 \\
-0.018 \\
-0.087\end{array}$ & $\begin{array}{l}(0.019) \\
(0.028) \\
(0.019)\end{array}$ \\
\hline
\end{tabular}

t $<<0.1 ; 0<0.05 ;$ Int: Interaction of poverty and lunch on height $p<0.1$ 
Table 6 Mean change in height SDS by type of lunch and ethnic origin in the English selective sample

\begin{tabular}{|c|c|c|c|c|c|c|c|c|c|c|}
\hline & \multicolumn{3}{|c|}{ School lunch } & \multicolumn{3}{|c|}{ Changed scheme } & \multicolumn{3}{|c|}{ Lunch prepared elsewhere } & \multirow{2}{*}{$\begin{array}{l}\text { Differences } \\
\text { in mean }\end{array}$} \\
\hline & $n$ & mean & $(S E)$ & $\bar{n}$ & mean & $(S E)$ & $n$ & mean & $(S E)$ & \\
\hline $\begin{array}{l}\text { Caucasian } \\
\text { Afro-Caribbean } \\
\text { Urdu } \\
\text { Gujarati } \\
\text { Punjabi } \\
\text { Other Asians } \\
\text { Others } \\
\text { Total }\end{array}$ & $\begin{array}{r}687 \\
226 \\
84 \\
161 \\
267 \\
38 \\
124 \\
1587\end{array}$ & $\begin{array}{l}-0.073 \\
-0.038 \\
-0.170 \\
-0.021 \\
-0.033 \\
-0.282 \\
-0.090 \\
-0.094\end{array}$ & $\begin{array}{l}(0.015) \\
(0.031) \\
(0.057) \\
(0.032) \\
(0.031) \\
(0.126) \\
(0.048) \\
(0.015)\end{array}$ & $\begin{array}{r}140 \\
26 \\
32 \\
46 \\
143 \\
22 \\
22 \\
431\end{array}$ & $\begin{array}{r}-0.115 \\
-0.122 \\
0.029 \\
-0.099 \\
-0.040 \\
-0.054 \\
-0.007 \\
-0.089\end{array}$ & $\begin{array}{l}(0.032) \\
(0.091) \\
(0.093) \\
(0.060) \\
(0.042) \\
(0.167) \\
(0.115) \\
(0.024)\end{array}$ & $\begin{array}{r}108 \\
11 \\
38 \\
56 \\
181 \\
19 \\
12 \\
425\end{array}$ & $\begin{array}{r}0.022 \\
0.154 \\
-0.071 \\
-0.123 \\
-0.029 \\
-0.318 \\
-0.023 \\
-0.062\end{array}$ & $\begin{array}{l}(0.037) \\
(0.141) \\
(0.085) \\
(0.054) \\
(0.037) \\
(0.179) \\
(0.156) \\
(0.024)\end{array}$ & $\begin{array}{l}* \\
- \\
- \\
- \\
- \\
- \\
- \\
-\end{array}$ \\
\hline
\end{tabular}

\section{Discussion}

The National Study of Health and Growth, the main aim of which has been the surveillance of growth of primary school children since 1972, has collected information on school meals and milk continually and systematically. Thus although it has not been specifically designed to assess welfare policy at school it can give information on the coverage of school meals and milk in different sectors of the community and useful pointers as to whether the changes in policy may have a beneficial or detrimental effect on the nutritional status of primary school children.

The analysis of rate of growth and receipt of free school meals and availability of school milk did not show consistent significant associations in children surveyed in the period 1972 to 1976 for free school milk and the period 1973 to 1979 for school meals. ${ }^{46}$ With the current analysis the purpose was to update information after the changes brought about by the legislation of the Education (No. 2) Act in 1980 were introduced.

We have analysed uptake of school meals and availability of school milk. In our view with respect to school milk the important issue is whether making milk available leads to an advantage in terms of rate of growth, but for school meals all children should have lunch of some sort and therefore the important issue is whether school meals confer an advantage in terms of rate of growth in comparison to lunch prepared elsewhere. We acknowledge that uptake of school meals will be influenced to a certain degree by the availability of the various options.

In comparison to the last decade the uptake of school meals in the representative English sample has changed in two respects: firstly the percentage receiving school meals has decreased from approximately $75 \%$ to $55 \%$, and secondly in the previous decade the service was used by the same proportion of children in all social classes while now it is mainly used by lower social classes and one parent families. In the selective sample the main characteristic of the service is the very high uptake by the Caucasian and Afro-Caribbean groups (above 80\%) in comparison to the Asian groups, with a $60 \%$ to $66 \%$ uptake. This would indicate that a cultural factor in addition to entitlement to free school meals and social characteristics influences the uptake of school meals.
Though most local authorities have some kind of arrangements for the Asian groups a sizeable number of parents in that community do not use the school meals scheme. In the three samples a large percentage of children in social classes IV and V and one parent families are receiving school meals and these are provided free of charge.

The availability of school milk followed a different pattern in so far as there was no association between availability of school milk and social class in any of the three samples. School milk is available in Scotland to more than half of the children in comparison to only a quarter in the English sample, in the main due to less provision for the 8-11 year olds in England. In the selective sample the availability reaches around two thirds of the children. Most of the children do not pay for the school milk.

As in our previous analysis based on school children in the 1973 to 1979 period $^{7}$ children receiving free school meals were shorter than children in other groups. This was also the case in the selective sample first studied in 1983. This difference was accounted for by the poorer social background of children receiving free school meals than that of other children. Therefore we can still say that the entitlement to free school meals in Britain identifies children who have on average a poorer nutritional status than their classmates. With respect to school milk the current arrangements only marginally favour children who may be of a poorer nutritional status, since no differences in height were detected between children to whom milk was available free, at a price, or not available.

The usual approach to a study of rate of growth is to analyse height at the second occasion adjusted for height at the first. When age groups are combined it is not valid to compare attained height between groups because of the increasing between child variance with age; height SDS is calculated for this reason. Mean change in SDS between two occasions represents a mean change in centile position between groups, and it is this that is referred to as rate of growth in this paper, as was used previously by Smith et al. ${ }^{16}$ The overall mean change in SDS was negative, indicating that the children in the analysis were shorter in the second year of measurement compared with children of the same age and sex in 1982. As children with no data on school meals or milk were excluded this does not necessarily 
represent a secular decrease in height. The interpretation of tables 4 and 5 with respect to school meals is that although free school meals reach a group of children who are already below average height, they neither gain nor lose in centile position from the provision of school lunch.

In this observational study we divided the groups according to poverty status because we expected that the current policy would have a more favourable effect in the poorer groups. We also assessed the ethnic groups separately because it is possible to conceive that the food policies would have different effects according to ethnic group. In respect to school meals, although some borderline significant associations and a significant association in the "not poor" English representative sample were observed, no consistent pattern emerged for the English or Scottish quasirepresentative samples. The only somewhat surprising result was that in Scotland children receiving school meals were shorter than other children, a finding similar to that previously reported for the poor Scottish group. ${ }^{7}$ In the selective sample, with one exception, there were no significant associations.

When analysing the effect of school meals policy on rate of growth it is worth keeping in mind the diversity of approaches in the country. Although the traditional meal is still the predominant type of school lunch in Britain many alternatives are now in existence. Therefore the group receiving school meals may be heterogeneous in relation to food acceptability and food composition. The same is true for those having lunch prepared at home. Packed lunch has become the most popular type of lunch outside the school meals scheme in the English representative sample, while lunch at home is the most popular in the Scottish representative sample. In the inner city areas a large proportion of Asian children go home for lunch. Thus in our analysis we are assessing the result of heterogeneous provision both of food prepared at school and food prepared at home.

With respect to school milk the association between availability of school milk and rate of growth was generally insignificant. It is likely that more general availability of milk would have no effect on the nutritional status of British children.

The school meals system is used more by the poor sectors in Britain and the entitlement of free school meals identifies children with poorer nutritional status than children not entitled to free school meals. We were unable to show a consistent association between midday meal at school and rate of growth in the representative and selective samples.

We would like to thank all the parents, children and helpers in each study area. We thank all our colleagues on the study team who have collected, processed and typed information and Professor W W Holland for his continued support and encouragement. The study is funded through the Department of Health and Social Security and the Scottish Home and Health Department.

Correspondence and reprints to: $\operatorname{Dr} \mathbf{R} \mathbf{J}$ Rona, Department of Community Medicine, UMDS, St Thomas' Campus, London SE1 7EH.

\section{References}

${ }^{1}$ Department of Health and Social Security. First report by the Sub-Committee on Nutritional Surveillance. Reports on health and social subjects. No. 6. London: HMSO, 1973.

${ }^{2}$ Department of Health and Social Security. SubCommittee on Nutritional Surveillance: Second report. Reports on health and social subjects No. 21. London: HMSO, 1981.

${ }^{3}$ Department of Health and Social Security. Third report by the Sub-Committee on Nutritional Surveillance. London: Committee on Medical Aspects of Food Policy, 1988.

${ }^{4}$ Irwig LM. Surveillance in developed countries with particular reference to child growth. Int J Epidemiol 1976; 5: 57-61.

${ }^{5}$ Cook J, Irwig LM, Chinn S, Altman DG, Florey CduV. The influence of availability of free school milk on the height of children in England and Scotland. J Epidemiol Community Health 1979; 33: 171-6.

${ }^{6}$ Baker IA, Elwood PC, Hughes J, Hones M, Moore F, Sweetman PM. A randomised controlled trial of the effect of the provision of free school milk on the growth of children. J Epidemiol Community Health 1980; 34: 31-4.

${ }^{7}$ Rona RJ, Chinn S, Smith A. School meals and the rate of growth of primary school children. $J$ Epidemiol Community Health 1983; 37: 8-15.

${ }^{8}$ Corry-Mann HC. Diets for boys during the school age. Medical Research Council. Special Report Series No. 105. London: HMSO, 1926.

9 National Institute for Research on Dairying (Reading) and the Rowett Research Institute. Milk and Nutrition, part 4. Reading: Pynter and Son, 1939.

${ }^{10}$ Central Statistics Office. Social Trends 18. London: HMSO, 1988.

11 Rona RJ, Chinn S. National Study of Health and Growth: social and biological factors associated with height of children from ethnic groups living in England. Ann Hum Biol 1986; 13: 453-71.

12 Altman DG, Cook J. A nutritional surveillance study. $J$ Epidemiol Community Health 1973; 66: 646-7.

13 Rona RJ, Altman DG. National Study of Health and Growth: standards of attained height, weight and triceps skinfold in English children 5 to 11 years old. Ann Hum Biol 1977; 4: 501-23.

14 Tanner JM, Whitehouse RH, Takaishi M. Standards from birth to maturity for height, weight, height velocity and weight velocity: British children, 1965. Part I and II. Arch Dis Child 1966; 41: 454-71; 613-35.

${ }^{15}$ Habicht JP. Some characteristics of indicators of nutritional status for use in screening and surveillance. Am J Clin Nut 1980; 33: 531-5.

${ }^{16}$ Smith AM, Chinn S, Rona RJ. Social factors and height gain of primary school children in England and Scotland. Ann Hum Biol 1980; 7: 115-24.

Accepted for publication October, 1988 